\title{
Carrying the War against COVID-19 into Ghanaian Communities: The Case of the Akan Community
}

\author{
Peter Arthur 1 (D) , Charles Ofosu Marfo, ${ }^{2}$ Elvis ResCue ${ }^{1}$ iD \\ Department of English, Faculty of Social Sciences, Kwame Nkrumah University of Science and Technology, Kumasi, Ghana. \\ 2 Department of Language and Communication Sciences, Kwame Nkrumah University of Science and Technology, Kumasi, Ghana.
}

\begin{abstract}
Ghana is seriously reeling under the weight of the scourge of the COVID-19; while the scientists are doing their best to provide information concerning the dos and don'ts of the disease, its communication to the people has been a huge problem. This paper uses the qualitative research approach and the Performance and Communication theories to investigate this challenge. The study isolates the Akan communities for this investigation and argues that the Ghana COVID-19 communication uses too many elitist approaches and the local language is rarely used. Again, the paper establishes that the communication falls short of considering the Akans as oral thinkers and completely ignores their ideological identities as a group of people who rely on oral structures in language and morality. The paper further observes that the COVID-19 communication in Ghana fails to recognize the subtle creative processes of translating concepts in English into Akan due to the influence of the contexts of contact. These challenges have resulted in minimum or complete lack of cooperation by Akan communities thus throwing the whole COVID-19 campaign into jeopardy. The paper recommends that the COVID-19 communication should reconfigure its approach to reach the Akan communities.
\end{abstract}

Correspondence
Peter Arthur
Email: pitah_7@yahoo.com
Publication History
Received 28th July, 2021
Accepted 23rd August, 2021
Published online 31st August, 2021.

KEYWORDS: COVID-19, Akan communities, Akan moral thought, communication and cultural shareability, Ghana.

\section{INTRODUCTION}

On the $12^{\text {th }}$ of March, 2020, a formal announcement of two COVID-19 infected persons who travelled into the country was made. Ever since, things have never been the same in Ghana. A special committee is formed by the Government to manage the pandemic and an important wing of this committee is the communication team. While the committee is working on communicating the dos and don'ts of the disease, its communication to the people has been a huge problem. This study therefore explores communications around the COVID-19 pandemic and how the protocols to be observed are communicated to the people, using the Akan communities of Ghana as a case study.

\section{Akan Communities in Ghana}

The Akan people are found in Ghana, West Africa, to be precise, and they form almost half the population of Ghana. Due to their large numbers, whatever affects them affects almost half the population of Ghana. Their language is also called Akan which belongs to the Kwa group of Niger-Congo language family. The Akan 
language has a number of varieties with Fantse (Fante), Asante Twi and Akuapim as the three major ones. Even though the Akan people are supposed to be a separate group in Ghana, several factors have cohered to make them share a lot of philosophy of life with the rest of Ghana. One of such philosophies is the Akan moral philosophy or thought which informs their behavior. Hence if reference is being made about behavior towards a pandemic, then their moral thought must be seriously considered. The Akan moral philosophy is the concept of good and bad. ${ }^{1}$

Gyekye's submission here is simple; "in Akan thought, goodness is not defined by reference to religious beliefs". ${ }^{2} \mathrm{He}$ asserts that his ethnographic research clearly divorced Akan morality from religion and that none of his participants or informants ever said that what was good was "because Onyame (God) had said so". ${ }^{3}$ He makes it clear that, "Akan moral thought, the sole criterion of goodness, is the welfare of the community." In other words, what drives the Akan moral thought is about the welfare of society and that what the society accepts to be good is what is good. In connection with what the Akan considers good or bad, this research later shows that most of the people in the Akan communities even do not know the dynamics of the pandemic and, therefore, the relationship between the don'ts of the pandemic and the "welfare of the community" is not too clear. And this lack of clarity obscures the Akan's meaning of good and bad of the pandemic. So far, the discourse for the COVID-19 pandemic has been scientific and the question is: to what extent has the scientific discourse been reduced to oral constructs for the traditional-minded Akan to follow? To what extent is President Akuffo Addo's declaration of state of emergency supported by a written document called the Executive Instrument (EI) 64, that there should be a partial lockdown in Accra and Kumasi and that people should follow the pandemic protocols, understood by the less educated people in these communities? Again, to what extent does the less educated or the non-elite in these communities understand terms and English words the content and cognition of which are in English?

\section{RESEARCH METHODOLOGY}

The methodological approach of this study is qualitative. Due to the partial lockdown, the operations of the print media had gone down considerably and most news-stands were closed. Sources from the print media became almost a problem. In addition, personal contacts became almost impossible. So, the authors decided to monitor the radio and TV stations, recorded programmes on COVID-19 and had some telephone interviews over a period of three weeks. The reason for relying on media materials stems from the fact that media gatekeeping and media agenda setting are very important aspects in health education and communication. The data is therefore mainly from the typical Akan speaking regions in Ghana and there is a reason for that. It must be pointed out that communication is not new to health education. ${ }^{5}$ But for this study, there is the need for segmented or a targeted audience. ${ }^{6}$ This calls for a specific society for the study with the view to interrogating the Akan people's cultural supportive system that facilitates reception of the messages being provided by COVID-19 communication campaign. ${ }^{7}$ Relying on qualitative research approach of the kind provided above and the Performance theory which sees the communication of the COVID-19 as a "situated behavior", 8 the study seeks to examine the extent to which this segmentation will also facilitate not only message reception but also the level of community knowledge as influenced by the Akan moral philosophy that influences them to do what is right. Again, the study relies on Credibility theory in communication. Self and Roberts see credibility in communication in terms of the "believability, trust, perceived reliability" of "the characteristics of those presenting, the message offered, the communication channel used, and the circumstances under

\footnotetext{
Kwame Gyekye, An Essay on African Philosophical Thought. New York: Cambridge University Press, 1987), 131.

Gyekye, An Essay on African Philosophical Thought, 131.

Gyekye, An Essay on African Philosophical Thought, 131.

Gyekye, An Essay on African Philosophical Thought, 131.

5 Charles Atkin and Kami Silk, Health Communication. In Don W. Stacks and Michael B. Salwen,(eds) An Integrated Approach to Communication Theory and Research: Communication Theory and Methodology (2 ${ }^{\text {nd }}$ ed.), (New York: Routledge, 2007), 489-523.

6 Seth Noar, Christiana Benac \& Melissa Harris, "Does Tailoring Matter? Meta-analytic Review of Tailored Print Health Behavior Change Intervention.” Psychological Bulletin. Vol. 133, no 4, (2007): 673-693.

Noar et al, "Does Tailoring Matter?" 673-693.

8 Richard Bauman, Verbal Art as Performance, (Illinois, Waveland Press, 1977), 26.
} 
which the message is perceived." In line with the above, the study also seeks to investigate how what they consider to be right is related to credibility in communication and how this leads to the awareness of the pandemic. Aspects of this society to be investigated also include their knowledge ${ }^{10}$ and economic gap. The period under study, however, covers both pre- and post-partial lockdown in Ghana, March to May, 2020, specifically Accra and Kumasi.

Again, it is instructive to know that concepts like the marginalized, the lower class, the poor, illiterate/ less illiterate, the masses and the under privileged are used interchangeably because they are more traditionally minded due to the fact that they rely more on oral language and philosophical structures to make meaning in their world. Co-incidentally, most of them do have very little of the national cake such that for them economic survival is a daily struggle and so are forced to eke out a living on subsistence basis. It must be pointed out however that the terms above do not mean exactly the same and that there are some cleavages that are difficult to define. In fact, even the literate can even belong to the marginalized once he/she fits into the category of the less or under-privileged community. The term "community" is defined by Coetzee" as "an ongoing association of men and women who have a special commitment to one another and a developed (distinct) sense of their common life." "In this study, the "sense of their common life" refers to a category of people of the Akan lineage who by virtue of economic or social standards cannot be considered to be the privileged.

\section{DISCUSSION}

The breaches of the Executive Instrument 64 (EI) point towards a lack of proper communication, the type of communication that relies on the moral definition of the society. The absence of a kind of communication that is not properly in sync with the moral thought of the people has led to apathy on the part of these Akan communities with regards to what the medical people tell them. Of course, there is a lot of information out there in the media and the educated elites in Ghana have access to the "looking glass" infrastructures in addition to the radio and there is even a glut of information there, a few fake ones though. But there are always available credible sources like CNN, BBC, Aljazeera and other international networks which do the right verification before putting information out there. The less- and non-educated do not have this privilege. All they have access to are the Akan radio stations and a few electronic media which use the Akan language. In Ghana, Peace FM and Adom FM are the only iconic stations for Akan programmes. It emphasized that the Media Commission has always viewed their method of news casting as being too adventurous and taking too many liberties with the standard manner of news-casting. This really has painted the picture that they are not serious broadcasters. Unfortunately, this negative image has affected not only Akan news-casting but Akan broadcasting as a whole. The educated elites would usually not listen to them citing some of the problems listed above. And it will interest one to know that some non-literate Akans have also bought into this negative perception of the Akan stations. For that reason, the Akan broadcasting stations are limited from the word go in reaching the public. The other challenge is the fact that they have not been able to develop the right ethnographic information to feed into their programs on COVID-19 and even though they might be doing their best, they lack information as to what to tell the non-literates to get them get in line with the fight against COVID-19. Unfortunately, other Akan stations in Kumasi share in these challenges, especially in the use of code switching and mixing which end up further confusing the non-literate.

The Akan radio and TV stations have not done much to communicate the full meaning of the pandemic to the members of the Akan communities. The development of using English terminologies and vocabulary in Akan news casting has not been helpful to the course of the fight against COVID-19. There are registers that have emerged with the COVID-19 pandemic that needs scientific explanation. They are concepts that the

\footnotetext{
9 Charles Self and Chris Roberts, Credibility. In Don W. Sacks, Kistern Campbell, EichhurnMichaels and B. Salwen (eds) $3^{\text {rd }}$ ed. Integrated Approach to Communication Theory and Research (London: Routledge,2019), 435.

${ }^{10}$ Emmanuele Gaziano and Cecelie Gaziano, Social Control, Social Change, and the Knowledge Gap Hypothesis. in D. Demers \& K. Viswanath (Eds.), Mass media, social control, and social change: A macrosocial perspective. (Ames, IA: Iowa State University Press), 117-136.

11

12 Pieter Coetzee, Morality in African Thought, In Pieter Coetzee and A. P. J. Roux, The African Philosophy: A Reader, New York: Routledge, 2002, 322.
} 
understanding of which can help in knowing the dynamics and control of the pandemic. For example, how does one expect the less- and non-literate to understand registers like pandemic, molecular testing, personal protective equipment (PPE), vaccination and social distancing if they are not properly explained in the Akan language? Unlike other registers like "wash your hand", "don't touch your eye" and "avoid hand shake" which directly translates into Twi as hohoro wo nsa, mfa wo nsa nka w'ani" and "nkyea obiara", respectively. The former registers lack direct or easy translation in Akan and for that matter the Akan presenters and newsreaders prefer to mention these registers in English. What they do is to mention these registers with an Akan tongue; i.e. 'Akanize' them. For example, an Akan presenter of Peace FM was heard saying $s \varepsilon$ wonya

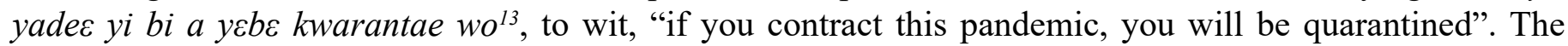
operative word in this sentence is "quarantine" but, unfortunately, an old lady in Yamoransah (a suburb of the Ashanti Region), who listens to an affiliate station of Peace FM, has missed the opportunity to understand the concept behind the idea of quarantine.

Some of the Akan presenters also resort to loose paraphrasing, thus missing the essence of the sentence

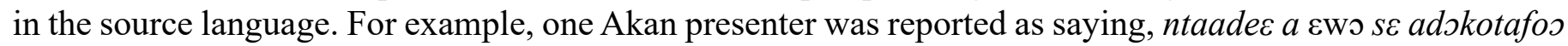
hye koraa no ebi nni $h \mathrm{~s}^{14}$, to wit, "the doctors do not have what they have to wear". And this is very vague because doctors, depending on their specialties, have their own garments and the audience does not know which of the garments being referred to here. Again, it is obvious it is PPE which is being referred to here and it is important the elderly, for example, those who did not go to school to understand what PPE exactly is to be well informed. Again, Kwame Sefa Kayi, the host of "Kokrokoo", a very popular programme on Peace $\mathrm{FM}^{15}$, revealed that a presenter in another station referred to those quarantined as a result of being suspected of having the disease as yamantam won, to wit, "those who have been strapped to confinement". Definitely, such a translation throws shivers down the spine of those whose only source of information are the Akan stations. Sometimes it is outright wrong translation. A reporter of Akoma $\mathrm{FM}^{16}$, Kumasi, referred to testing the samples

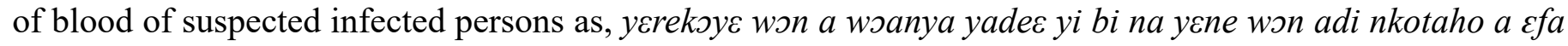
won mmogya no nsohwe to wit, "the samples of the blood of those who have been infected are going to be tested". This translation is bizarre for the term "test" has been transliterated. so, instead of nhwehwemu, the reporter uses $n s \jmath h w \varepsilon$ which literally glosses as "test". The non- and less literate are made to confront such problems on daily basis and the result is that they lack the opportunity of appreciating the real import of the COVID-19 challenges. This inadequacy does not make them fully understand what is going on. Clearly, even though these Akan stations are using Akan to communicate, the orality of the message has not been properly received and, in fact, some of the Akans in the communities believe the whole business of the campaign against the pandemic is a hoax and, therefore, cannot be taken seriously. They do not see why their liberties should be curtailed: life must go on as usual.

Another challenge is that the less-and non-literate cannot even pronounce the registers of the COVID-19 all because they are in English. The Joy FM ${ }^{17}$ morning show hosted by Daniel Dadzie played a host of pronunciations and the manner in which the interviewees pronounced them appeared very funny. To the authors, however, it is not funny at all. One woman who was made to pronounce "corona virus" after seriously fumbling with the pronunciation said in Fantse $s \varepsilon$ ebsn adze $o$, se ebsn adze $o^{18}$, to wit, "and all the gamut of issues", indicating not only lack of seriousness with the pronunciation but also not with the entire pandemic as well. And she laughed! The whole campaign has been reduced to a joke. So, why should she risk her daily survival by listening to COVID-19 education which tells her to stay at home and to avoid contact with an infected person? The fact is the Akan stations are not explaining the concepts of these registers. One even wonders if it is necessary for them to pronounce the registers in English since their target listeners did not go to school. What they need is an understanding of what is happening as they need to conform to the behavior prescribed by the EI.

To make matters worse, the non- and the less literate in the Akan communities are heavily prejudiced

\footnotetext{
13 Peace News, Accra, 17/04/2020

14 Akoma FM morning show, Kumasi, 13/04/2020

15 Peace FM, "Kokroko", Accra, 17/04/2020

16 Akoma FM morning show, Kumasi, 13/04/2020

17 Joy FM morning programme, Accra, 09/04/2020

18 Joy FM morning programme, Accra, 09/04/2020
} 
in determining who gets infected and who does not. First, the disease was made to be seen as foreign even in the main stream media houses which use English. It was known as a Chinese disease and people were only worried because they had relatives in China. Also, the media made it look like the pandemic had reached Europe and America. Then came fake theories that the Black man was resistant to the disease. Such fake news was all over social media. Such fake news even received attention in some of the mainstream media houses. Then two people tested positive in Ghana. The whole reportage skewed the risk of infection towards travelling. The narrative was a very welcoming one for the Ghanaian. The idea that the Ghanaian media presented the whole COVID-19 situation as a travel emergency did not prepare Ghanaians psychologically and the most vulnerable of this state of unpreparedness is the non-literate who listen to the literate for information. This has far reaching implication for the less privileged or the low income people who hardly travel across the borders of the country. That is, the assumption is that if the disease is for the rich, then, let it be. The low-income group from whom most of the illiterate and less illiterate come can therefore not be bothered. Then all of a sudden, the President announced that people should stay in their houses because of the 'rich man's disease'. Something does not seem to work well with the logic here. Those in the low income bracket are apathetic and cannot be bothered about lockdown; after all, he has to go out to be able to survive and this was reiterated by one caller on Kessben FM, "now they say we should not go out and work, so how do we survive?"19 Linguistically, the use of the deictic "they" means a lot to the authors. The circumstantial "now" presupposes an anterior time which used to be good and which is now being disrupted by "them" and so "them" is disruptive. The use of the pronoun "they" is distancing the speaker from whoever is giving the directive and that emphasizes the idea of apathy early on suggested. In sum, what the President is saying lacks community acceptability and therefore cannot constitute oral moral thought of the Akans.

Unconsciously, the class war of "we and them", the class or knowledge gap is gradually rearing its head in the fight. ${ }^{20}$ A close monitoring on the airwaves indicates very little involvement of the poor or the marginalized in the discourse on the fight against the pandemic. Their voices are not played on TV and radio. In radio talk shows, they are not called to contribute so that listeners hear their side of the story. On the only occasion they were heard on Joy $\mathrm{FM}^{21}$, they were being subjected to ridicule by being made to pronounce COVID-19 registers and Gaziano and Gaziano are right in their postulation that "knowledge gaps may also increase tension in the social system" 22 . The laughter as a result of the mispronunciation is more punitive because it lampoons and demeans those in that social category. This prompted one to look for some of the Akan radio or TV stations sympathetic to the non-literate. After a long search, two stations, Akoma FM and Pure FM, all in Kumasi were chosen. Pure FM's morning show was being hosted by Kwame Adinkra. Kwadwo Marfo, one of the panel members for the programme, revealed that one of the leading members of the New Patriotic Party, Yaw Boafo, was lamenting, about why people have to steal whenever the government releases money for intervention programmes for the poor ${ }^{23}$. He was speaking in connection with the food that the NPP Government was giving out to the poor as part of the measures to mitigate the difficult circumstances of the poor during the COVID-19 lockdown period. He sounded very sad that such a good intervention could be marred by greedy government officials who could cash in on it. The boundary between the literate and the illiterate who are mainly traditional thinkers or who derive their morality from the oral source are now clear. The tension described by Gaziano and Gaziono shows up and little wonder the under-privileged respond by appearing apathetic to the course for the fight against the pandemic.

\section{Lack of Cultural Shareability of the Ghana Covid-19 Communication}

From the analysis, it is obvious the meta discourse of the textual construction of the Ghana COVID-19 communication unconsciously practices social exclusion of the marginalized. There is a need to establish that the Ghana COVID-19 communication of the pandemic is essentially middle-class and barely addresses the concerns, the social and cultural circumstances of the lower class, most of whom happen to be traditionallyminded. This is premised on the fact already established that the preponderance of the language used has been

\footnotetext{
19 Kessben FM Saturday morning program, “Amansan ntie” hosted by Omanhene Adu Boachie, Kumasi, 10/04/2020

20 Gaziano and Gaziano, Social Control, Social Change, and the Knowledge Gap Hypothesis, 117.

21 Joy FM morning programme, Accra, 09/04/2020

22 Gaziano and Gaziano, Social Control, Social Change, and the Knowledge Gap Hypothesis, 117.

23 Pure FM morning programme hosted by Kwame Adinkra, Kumasi, 14/04/2020
} 
the English language. One needs to concede here that some of the experts in communicating this pandemic cannot even express themselves well in Akan or any of the local languages. The Akan stations, with the exception of Adom FM, Peace FM and Kessben FM, mostly do code switching and mixing on daily basis and in most cases resort to the English language and sometimes disastrously translate some of technical terms concerning COVID-19.

The campaign as an entextualized text is "the process of rendering a given instance of discourse a text, detachable from its local context" ${ }^{24}$ can be de-contextualized ${ }^{25}$. Urban draws from Bauman and Briggs' concept of entextualization, that removing a text from its context and placing it in another, provides a lot of support for analysis. ${ }^{26}$ Clearly, the communication text has left out the marginalized, most of whom by virtue of being illiterate do not follow such elite stations. Simply put, the process of removing the text from the context of the middle class to the lower is a failure; the reason being that this exclusion implies that this communication text is personal to only one class of people and lacks enough characteristics to make it detachable, a text that has been lifted from its context and yet to be re-contextualized in another context. In other words, the communication of the Ghana COVID-19 campaign does not move from what is written in the form of an EI, or what is found in the health textbooks to what is oral, or what the Akan society considers to be right. The exclusion of this audience sub-segment is very crucial to the understanding of the behavior of the lower class, the illiterate or the traditionally minded person. In the performance theory, the audience is in the best position to evaluate performance only when they share a common culture with the performer and that is the concept of 'shareability'. In the communication theory, this is referred to as interpersonal communication. The audience evaluate how well the performer is expressing the interpretive cues of the performance and based upon that can identify a good or a bad performer.

To bring this to the communication in the fight against the pandemic in Ghana, one has to consider the following question; has the communication of the campaign against the pandemic identified the interpretive cues of the marginalized? The Luv FM morning programme, Luv in the Morning, hosted by David Akweteh gives an idea to the answer to this question. Most of the callers were of the opinion that it was a matter of survival and that if the person was hungry, he would pay deaf ears to instructions to make him stay at home ${ }^{27}$. This statement drew the authors' mind back to the caller during a Kessben FM programme who questioned that, "they say we should stay home; what are we going to eat?"28. Another reason why the less educated or traditionally-minded Akan cared very little about social distancing was their belief that COVID-19 did not exist. A caller who identified himself as David to Luv FM Wednesday programme revealed that he met some girls who were saying the pandemic was spiritual and of course, if it was spiritual then it was not physical and did not need all the so-called safety protocols being drummed around ${ }^{29}$. The fact is the traditionally-minded Akan, who rely on Akan radio and TV stations do not have the benefit of the proliferation of information on radio and TV stations which speak English and the result is demonstration of pure ignorance with regard to spread of the pandemic.

Apart from the communication text not addressing the survival ideology of the marginalized, the text also fails to identify the ideological identity of the marginalized. The question is how much is the communication constitutive of the cultural identity of the marginalized? There is no problem with the middle class communication, but the analysis has indicated the difficulty in transplanting it in toto from the middle class to the lower class. The problem with this difficulty is that of 'addressivity, ${ }^{30}$ the mutual orientation of the middle class text and that of the lower class. But before the middle class communication text can fit into the lower class communication text, one of the prerequisite is identity because, quite clearly, the middle class do not share the same identity with the lower class. If the marginalized are also part of the audience of the communication, then the communication should investigate what the marginalized bring to the table. If those

\footnotetext{
${ }^{24}$ Greg Urban, Engtextualization, Replication, and Power. In Michael Silverstein and Greg Urban, (eds) Natural Histories of Discourse, (Chicago: Chicago University Press, 1996), 21.

25 Clifford Geetz, The Interpretation of Culture.( Basic Books, 1973).

${ }^{26}$ Urban, Engtextualization, Replication, and Power, 21.

27 Luv FM morning programme, Kumasi, 15/04/2020

28 Kessben FM Saturday morning program, “Amansan ntie” hosted by Omanhene Adu Boachie, Kumasi, 10/04/2020.

29 Luv FM morning programme, Kumasi, 15/04/2020.

${ }^{30}$ Mikhai Bakhtin, Speech Genres and Other Essays. (Texas: University of Texas Press, 1986), 99.
} 
charged with the COVID-19 communication fail to do this, there is a problem involving traditionally-minded Akan in the fight.

The first of the various aspects of cultural identity to consider here is language. It has already been mentioned that language is a barrier to communication but one needs to see how it affects understanding of the manner in which the traditionally-minded Akan responds to his cultural identity through the use of language. It is refreshing to note that during the press briefing of the Minister of Information, it was made known that, henceforth, all radio and TV stations were to translate what they were saying concerning COVID-19 into the local languages, a directive that has not been followed ever since it was given. But assuming that it is being followed, is that all there is to the use of local language? No. For example, using the Akan language on all stations could be fantastic. But there is a need to consider the culture that produces the language and the cultural inclinations of the people who are going to speak it in the media. This is 'shareability.' To what extent does message share with the intended listeners or viewers? The following are critical in the communication context: Who is speaking? In what language? How is he speaking, where is he speaking and to whom is he addressing? All these are necessary to make what he is saying complete.

In a radio discussion on Luv FM ${ }^{31}$, Dr. Paa Kwesi Baidoo strongly suggested the involvement of traditional leaders in the communication process and he is perfectly right because that is an important ingredient in the shareable constituents of the communication. The people know the traditional leaders to be their caretakers and that they stand for and defend their wellbeing. In the past, the Ashanti King was the number one war leader and in history. The Ashanti people therefore call their kings, yewura (our Lord), and that tells the extent to which Ashanti people revere their king. This applies to all Akan speaking people. In addition, the kings as traditional leaders possess the linguistic skills to appeal directly to their people. They reside in the same area with their people and the most important shareable culture in connection with this is that the leaders are the custodian of the culture of the people. Their subjects pay special attention to what they say. For an example, when Otumfour Osei Tutu 11 was mourning Nana Afia Kobi's (his mother's), he ordered that the whole city stay indoors and it was followed to the letter. The whole Kumasi was dead quiet. So why is it that at this time when the Ghana Health Service, and for that matter the government, is issuing directives and even though soldiers have been deployed on the streets to check "recalcitrant" citizens, people still flout the directives? Again, imagine a doctor in his immaculate white coat with the stethoscope on his/ her neck or a nurse in a white or green gown standing in front of citizens of a village in any part of Central, Western, Bono, Ahafo or Ashanti regions struggling with the Akan language. The authors are not referring to ethnic exclusivity but these health officials will be seen as strangers and in communication, the medium is the message. In 'shareability', who says what - that is the messenger of a message - is important. Again, when Kwame Amor, a popular Akan news reader with Peace $\mathrm{FM}^{32}$, while presenting the news burst into singing about COVID-19 as given below, the elite might take that for a joke, citing problems of breaching general ground rules for news reading.
Akan
Hohoro wo nsa, fa samina ye
Hohoro wo nsa, fa samina ye
Hohoro wo nsa o, fa samina ye

\begin{abstract}
English
Wash your hands, use soap

Wash your hands, use soap

Wash your hands o, use soap
\end{abstract}

However, he was doing a lot of oral communication; melody, rhythm, syntactic and phonetic parallelism and all the semantico-lexical materials add up to the message being transmitted to enable the message stick to memory. Clearly, communication in Akan, a primarily oral language which keeps information in the head, ${ }^{33}$ is not the same as communication in English, which keeps information on paper.

The next challenge in the addressivity of the COVID-19 communication is how the local language is communicated - the technicality in the communication, the idiom and the conventions. Akan is an oral culture as has been noted earlier and, unlike the written culture that keeps information on the paper, it keeps information in the head. This marks a remarkable difference between learning the written word from

31 Luv FM morning programme hosted by David Akwete, Kumasi, 15/04/2020

32 Peace News, Accra, 17/04/2020

33 Walter Ong, Orality and Literacy: Technologizing of the Word, (New York: Matheun, 2002). 
the oral one. To this end, oral delivery follows a particular psychodynamic that one should pay particular attention to and in this area, a cue can be drawn from Walter Ong's concept of the psychodynamic features or characteristics of orality. To make things stick, repetition is very essential in utterance as is seen in the text provided above. The oral tend to use memory cues like the redundancy, when the sentences are connected by connectives, and parallelism, when various linguistic structures are repeated for the sake of meaning-making. The authors keep singling out Adom FM and Peace FM as prototype Akan stations due to the manner in which they demonstrate some of these oral dynamics. In their news reading, they keep repeating and the elite accuse them of verbosity. The Performance theory exonerates them because they do so to make information stick in the mind. Another oral approach is the copious way materials are exaggerated for the sake of memorization. The same message is given in so many ways; in proverbs, in anecdotes, in analogy, in various tropes and so forth. This is the stock-in-trade of the linguist in the palace of the Akan chief. And when Adom FM and Peace FM apply these techniques, they are accused of frivolity even by the Media Commission of West Africa. Again, the Performance theory exonerates them because they are using copious means ${ }^{34}$ as memory cue. Epithets that recount historical antecedents of the glorious past are used to tell a story. All these are meta discourses ${ }^{35}$, discourses about other discourses, which irrigate traditional meanings and they have the power to (re)construct identity and meaning in a way that is peculiar to the Akan people. There are other techniques and conventions which cannot be treated in this space but the point here is that it is not merely providing a jingle with an Akan voiceover that constitutes communication to the Akan. It is not merely speaking in English and translating it into Akan that constitutes communication to the Akan. The COVID-19 communication lacks all these shareable cultures and therefore the underprivileged and traditionally-minded Akan finds it difficult to connect with the information and messages about COVID-19. There is information all right, but there is no communication. One thing that should be noted is that identity problems have the potential of creating credibility challenges for both the sender and the receiver

\section{Lack of Credibility}

As stated above, challenges in addressivity creates credibility problems in COVID-19 communication. In health communication, Knobloch-Westerwick et al define credibility as situations where "people are more likely to believe sources that look and think like them". ${ }^{36}$ There must be a mutual orientation between the sender and the receiver because health education is a mediated communication and that implies that one should pay attention to the mediation. The mediation, according to analysis is cultural shareability. This principle is therefore the basis upon which the receiver identifies a shared culture which makes him/her feel involved in a communication process. However, the discussion points to the fact that the lower class or the marginalized has been ignored in all the processes and media of communication and their behavior of noncompliance to the COVID-19 communication bares ample testimony to that. The marginalized feel cut off from the communication process because those handling the communication have not considered any of the marginalized survival ideologies like food security, language, human dignity, survival and cosmology, which are key to understanding their cultural and social circumstances. This failure is a serious breach on the part of the COVID-19 communication team. It is not just a failure but a credibility issue because they have failed to "look and think" like their destination. ${ }^{37}$

When the marginalized ignore social distance instructions by the EI, a written document that fails to address his/her oral way of doing things, he/she ignores the directives and therefore a situation occurs in the Ashaiman and Sunyani markets where men and women fail to adjust to new behavior as prescribed in the EI. When Kwadwo Marfo became skeptical about the use of money meant for the food distribution project, he did not trust officialdom in charge of the project, a mistrust that is the result of credibility on the part of officialdom. When Aba of Apewosika, Cape Coast, complains of lack of money to take care of her family,

\footnotetext{
34 Ong, Orality and Literacy: Technologizing of the Word.

35 Barbara Babcock, The Story in the Story: Metanarration in Folk Narrative. In Richard Bauman, Verbal Art as Performance. (Illinois: Waveland Press, Inc., 2015), 6.

36 Silvia Knobloch-Westerwick, Cornelia Mothes, Benjamin Johnson, Axel Westerwick and Wolfgang Donsbach, Political Online Information Searching in Germany and the United States: Confirmation Bias, Source Credibility, and Attitude Impacts. Journal of Communication, 65 (2015): 489-511.

37 Knobloch-Westerwick, et al, Political Online Information Searching in Germany and the United States, 489-511.
} 
she is blaming a system that has put her in a disadvantageous position, a system run by officialdom ${ }^{38}$. The fact is that the COVID-19 communication text, as stated earlier, is fixed and permanent in its context, the middle class context, and cannot be lifted to nuance the culture and living circumstances of the lower class, the traditionally-minded. This break in cultural transmission is also a break in communication fueled by lack of credibility on the part of the communicator. ${ }^{39}$

In fact, Aristotle places the burden of credibility on the ethos of the communicator. ${ }^{40}$ KnoblockWesterwick et al. are in agreement with Self and Roberts that credibility is the "communicator's ability to inspire confidence and belief in what is being said". ${ }^{41}$ Quite frankly, if this target group does not respond favorably to the COVID-19 communication text, we can only say that it is because the text fails to inspire confidence and belief in the message. Indeed, the marginalized see the COVID-19 as a strange phenomenon because its ethics and moral standards are different from those that the marginalized, majority of whom are traditional thinkers, are used to. Also, not much, as seen in this analysis, is done to address this knowledge difference in the COVID-19 communication and if the messenger is not believed in, the message suffers the same fate.

\section{Consequences of Disconnected Text}

There is clearly a break in cultural transmission and communication generated by this credibility challenge and this, in turn, creates a disconnect between the communicator and the audience or the receiver. As a result of this disconnect, the challenges may range from ignorance, fear, stigma and survival practices.

Ignorance on the part of the less educated being the receiver in this communication is obvious. After all, they are not part of what is being communicated so why should they bother to understand what is going on? During a radio programme, the Diary on Luv FM ${ }^{42}$, in which one of the authors was a panel member, Erastus Asare Donkor, a reporter from that station was called from Duayaw Nkwanta in the Bono Region and he reported that there was nothing to indicate that they were respecting social distancing. The people were 'clubbing' together. There were people who were in buses coming to Kumasi where there was a partial lockdown. Others were bristling in the markets. He concluded that it appeared these people knew nothing of the EI on social distancing and if they had, they clearly did not understand it. During that same programme, the host, David Akwete, revealed that a friend's mother was seventy years old and in spite of all the goings-on during this virus-threatening period, the friend vowed to organize a communal birthday party for her. Easter Sunday, 12/04/2020, came with a lot of interesting stories with regard to people flouting the EI. The Peace FM 6am news reported on Easter Sunday that forty-six (46) people were arrested on Saturday, 11/04/2020, at Akaporiso, a suburb in Obuasi for congregating for nuptial celebration, completely oblivious of the EI. The report indicated that it was a huge crowd, but the rest run away and the Police was able to arrest only 46 of them. Kessben $\mathrm{FM}^{43}$ in Kumasi also reported that on the Easter Sunday, people milled up the Chorkor Beach in Accra and it took the intervention of the Police to disperse them. A few of them were rounded up. Other radio stations were also complaining about the EI not being followed in communities like Bantama and Tafo in Kumasi. In Tafo, it was even reported in the news that the Police had to intervene in one such gatherings resulting in the shooting of a young $\operatorname{man}^{44}$. The Police has since denied this, describing the incident as not related to the COVID-19 campaign as the victim was smoking wee.

Furthermore, this disconnect in communication produces a sense of apprehension among the marginalized. They do not know how to react to the communication which they do not understand and this throws them into a state of confusion and the first in this context is fear. Joy News ${ }^{45}$ reported that the youth of Efutu of the Efutu Senya district in the Central region of Ghana barricaded the road leading to the town

\footnotetext{
38 Joy News, Joy FM, 99.7, Accra, 14/04/2020

39 Michael Silverstein and Greg Urban (eds). Natural Histories of Discourse. In Michael Silverstein and Greg Urban, Natural Histories of Discourse, (Chicago: Chicago University Press, 1996).

40 Self and Roberts, Credibility, 436.

${ }^{41}$ Knobloch-Westerwick, et al, Political Online Information Searching in Germany and the United States, 489-511.

42 The Diary, Luv FM afternoon programme, Kumasi, 06/04/2020

43 Kessben FM Saturday morning program, “Amansan ntie” hosted by Omanhene Adu Boachie, Kumasi, 10/04/2020

${ }^{44}$ Kessben FM Saturday morning program, "Amansan ntie” hosted by Omanhene Adu Boachie, Kumasi, 10/04/2020

45 Joy News, Joy FM, 99.7, Accra, 13/04/2020
} 
and the reason was that they were protesting against the fact that the senior high school there was going to be used as an isolation center. Some of the Efutu youth were interviewed and they did not hide their fear that people suspected of being infected with COVID-19 going to be housed there were likely to infect the people around. Joy News ${ }^{46}$ again reported that the people of Akon and Brafiyaw in Cape Coast were also up in arms against the authorities for selecting Aggrey Memorial Senior High School as an isolation center. There is irony of circumstances here. The marginalized behaved as if they were not bothered, so why were they afraid? This is because they are ignorant about the disease and this unfortunate situation was due to the fact that the demonstrators did not even know that people under quarantine are not allowed to mix up with the population. Indeed, due to fear, some of the marginalized might not even show up in the hospitals when attacked with COVID-19 and symptoms of the pandemic surface. They will keep to themselves till they reach crisis period and die and in connection with this, five dead bodies were collected from the streets of Kumasi. Some of those who died, when alive were heard coughing a day before they died.

The second sense of apprehension is stigma against those suspected of the COVD-19 disease. Two women went to Sikka FM on Monday, 13/04/2020, crying that they sell "diehuo" (a kind of paste food popular among people of the Northern extraction, which is also popular in Kumasi) in Mary Dwomu in Ashtown, Kumasi and some people had been rumoring that one of the sellers had COVID-19. This had scared their patrons to coming to buy the food from them leading to a total collapse of their market. Maali and Theresa were virtually on their knees begging patrons to come back adding they were prepared to subject themselves to tests. One can imagine the economic challenge these sellers are going to face. How they were going to take care of their family and other dependents was hanging in the balance all because the people around them know next to nothing on who a COVID-19 patient is and where he/she should be. Such ignorance, of course, results in unfortunate speculations that seriously harm the stigmatized.

Moreover, another expression of apprehension is the go-and-die attitude on the part of the marginalized. They may be aware of the dangers of COVID-19 but they dare go out and work for their survival. Of course, there are some critics who also believe that the survival factor is only a subterfuge to flout the directives. These critics reason that if kayayes (head porters), could raise money to contribute to the campaign of some of the parties in Ghana, then one cannot help but have some reservations about the degree of penury expressed by them during the lockdown. Be it as it may, Joy News ${ }^{47}$ reported the situation in the Ashiaman Market in the Greater Accra Region where the people there were behaving with complete disregard for the EI and one can easily link this to the story of Aba in Apewosika, a village behind University of Cape Coast. She was a fish monger and her customers were from the university community. She complained that as a mother of four, she felt neglected by the government and claimed that her creditors were on her neck. She could not provide food for her children ${ }^{48}$. Obviously, such a person would not reject an "opportunity" to sell in an overcrowded market.

Finally, the expression of apprehension within the context of this study is survival practices. Because of the indifference as a result of lack of education, they adopt different strategies to go round the directives of the EI which they consider inimical to their survival. Market women in Juaben of the Ejisu Juaben district area have developed new strategies to engage their customers since the lockdown stopped them from trading. It was reported on Luv $\mathrm{FM}^{49}$ that they had removed all their merchandise from the market to their houses where they were doing brisk business with their customers. Stores which are not selling food or food related items as stipulated in the EI, have managed to get the authorities to allow them to operate. Shopkeepers who were selling things other than food quickly started selling food.

\section{CONCLUSION}

The thinking and attitude towards the pandemic by the Akan community is heavily influenced by their moral philosophy. The Akan ethical and moral philosophy is purely hinged on orality. In this case, moral philosophy to influence attitudes in Ghana must pay attention to this oral approach. The problem therefore arises when

\footnotetext{
46 Joy News, Joy FM, 99.7, Accra, 13/04/2020

47 Joy News, Joy FM, 99.7, Accra, 13/04/2020

48 TV3 News, 09/04/2020

49 Luv FM morning programme, Kumasi, 06/04/2020
} 
this group, who is basically oral in thinking, is treated to a communication that is structured along written cultural considerations, and this is what seems to be playing out in the communication for the COVID-19 campaign to the marginalized and/or less educated in the Akan communities, who constitute the masses. Their ideological identities are ignored and almost all information is given in English. The Akan language that is used in the campaign completely ignores the linguistic salience of originality and authenticity of the dynamics of the language.

Furthermore, the traditional leaders who are known to the communities and who, as partners in communication, can be in the best position to express ideas in the manner the communities will understand, are pushed to the side tracks and made to be on-lookers. It has also been observed that, indeed, there is no cultural shareability between those in the communities and the communication being used to fight the pandemic. It has been made clear that the result of this lack of cultural shareability results in a credibility challenge on the part of the communicators, which further creates a gap between the communication and the communities.

It is quite evident that the communication for COVID-19 in Ghana needs a holistic approach that will reach people of all cultural and socio-economic backgrounds. The current communication fails to make less or non- educated Akan see what is bad in COVID-19 because it does not address the traditional notion of what they know to be good or bad. Whether in health education or health communication, this targeted group of people believe that what is good is defined by the community ${ }^{50}$ and basing the communication on what the community believes to be good will involve the people in the Akan communities in the fight.

\section{ABOUT AUTHORS}

Peter Arthur( $\mathrm{PhD})$ is a Senior Lecturer in the Department of English, Kwame Nkrumah University of Science and Technology, Kumasi-Ghana.

Charles Ofosu Marfo $(\mathrm{PhD})$ is a Professor in Linguistics in the Department of Language and Communication Sciences, KNUST. He has done a lot of research on the role of linguistics in the Akan language and has many publications to his credit.

Elvis ResCue (PhD) is a Lecturer at the Department of English, Kwame Nkrumah University of Science and Technology, Kumasi-Ghana. He holds $\mathrm{PhD}$ and MA in Applied Linguistics from Aston University, Birmingham-UK, and BA in Linguistics with English from the University of Ghana, Legon. His research interests lie in the area of Discourse Analysis (Language and Literary texts), African and General Linguistics, Language Contact/Sociolinguistics, Media Language, and Language Policy and Planning.

\section{BIBLIOGRAPHY}

Adler, Freda., Gerhard Meuller and William Laufer. Criminology and Criminal Justice. New York: McGraw Hill, 2001.

Atkin, Charles, and Silk Kami, "Health Communication." In Don W. Stacks and Michael B. Salwen, (eds) $A n$ Integrated Approach to Communication Theory and Research: Communication Theory and Methodology (2 ${ }^{\text {nd }}$ ed.), (pp. 489-523) New York: Routledge, 2007.

Babcock, B. The Story in the Story: Metanarration in Folk Narrative. In Richard Bauman, ed. Verbal Art as Performance. Illinois: Waveland Press, Inc. 2015

Bakhtin, Mikhai, Speech Genres and Other Essays. Texas: University of Texas Press, 1986.

Bauman, Richard Verbal Performance. Illinois: Waveland Press Inc, 1977.

Coetzee, Pieter, Morality in African Thought. In Pieter Coetzee and A. P. J. Roux, The

African Philosophy: A Reader, New York: Routledge, 2002.

Gaziano, Emmanuel and Cecelie Gaziano, "Social control, social change, and the knowledge gap

\footnotetext{
${ }^{50}$ Gyekye,. An Essay on African Philosophical Thought, 131.
} 
Hypothesis". In D. Demers \& K. Viswanath (Eds.), Mass media, social control, and social change: A macrosocial perspective. (pp. 117-136). Ames, IA: Iowa State University Press, 1999.

Geetz, Clifford, The Interpretation of Culture. Basic Books, 1973.

Gyekye, Kwame, An Essay on African Philosophical Thought. New York: Cambridge University Press, 1987.

Knobloch-Westerwick, Silvia, Cornelia Mothes, Johnson Benjamin, Westerwick Axel., \& Wolfgang

Donsbach, "Political Online Information Searching in Germany and the United States: Confirmation Bias, Source Credibility, and Attitude Impacts.” Journal of Communication, 65, (2015): 489-511.

Noar, S., Benac C. \& Harris, Melissa S. Does Tailoring Matter? Meta-analytic Review of

Tailored Print Health Behavior Change Intervention. Psychological Bulletin. Vol. 133, no 4, (2007): 673-693.

Ong, Walter, Orality and Literacy: Technologizing of the word. New York: Matheun, 2002.

Self, Charles and Chris Roberts, "Credibility." In Don W. Sacks, Kistern Campbell, Eichhurn Michaels and B. Salwen (eds) $3^{\text {rd }}$ ed. Integrated Approach to Communication Theory and Research pp. 435-462. London: Routledge, 2019.

Silverstein, Michael. \& Greg Urban, (eds). Natural Histories of Discourse. In Michael Silverstein and Greg Urban, Natural Histories of Discourse, Chicago: Chicago University Press. 1996.

Urban, Greg, "Engtextualization, Replication, and Power." In Michael Silverstein and Greg Urban, (eds) Natural Histories of Discourse. Chicago: Chicago University Press, 1996. 